\title{
Hegemony, Exclusion and Equivocal Identities: Reflections on Israel's Arab Minority in Sayed Kashua's Dancing Arabs
}

\author{
Neha Soman \\ ICSSR Doctoral Fellow, Dept. English, Bharathiar University, neha.efl@buc.edu.in, \\ https://orcid.org/oooo-0003-3900-3607O
}

\begin{abstract}
Social consciousness forms in allegiance with the moral and political hegemonic power structures. Gramsci's organic ideology defines this condition of hegemonic system where societal leadership is practised by the dominant class. With the emergence of cultural studies the prevailing hegemonic discourses are challenged, but defining liminality in this spectrum is still an ongoing process. In this context, the essay aims to demarcate the problematic aspects of personal and national identities against the hegemonic power structures, specifically with the case of the Arab minority in the State of Israel. Apart from the fundamental facets of hegemony, the aberrant conflict between nationalism and citizenship emerging from Israel's legitimacy as a Jewish democratic State, places the Arab Israeli identity in question. These arguments are validated through the fictional life narrative of Israel's prominent Arab writer Sayed Kashua. His novel Dancing Arabs (2002) recapitulates the reality of being an Arab in Israel. The impeccable representation of identities in question hinges the repercussions of hegemony and social exclusion on both subjective and national levels. Standing on the critical platforms of Gramsci's political theory of "hegemony" and Stuart Hall's cultural theory of "identity", the text is closely read as an artefact of resistance with emphasis on personal, political and philosophical discourses on the identity of the Arab minority in Israel. The essay traverses through the ethnocentric status of Israel's social structure which disorders the recognition of Arab identity and identifies the conflict as a potential hindrance to peaceful coexistence in Israel's near future.
\end{abstract}

Keywords: Hegemony, Identity, Arab Minority, Israel, Social Exclusion

\section{Introduction:}

"[I]dentity is never a priori, nor a finished product; it is only ever the problematic process of access to an image of totality." (Homi K. Bhabha)

The notion of identity is abundantly expounded in scholarship and continues to be a potential subject considering the transitional state of human societies. Its varied meanings from selfsameness ( Gubrium \& Holstein, 2000) to a construct regulated by socio-cultural factors (Schachter, 2005) highlight dynamic ways to construe the term. However, demarcating the definition of identity to man's selfsameness would be scant to comprehend its significance since identities gauge who or what an individual is in responsive to the social setting. Theories of human evolution and social learning have accredited the fact that the apogee of human growth is found in man's effective interaction with the environment. (Piaget 1936, Bandura 1977, Vygostki 1978) These studies argue that man has not evolved in seclusion but the influence of his social environment has elevated the process of his progression. Man's behaviour is identified, altered and esteemed in accordance with his social space. The influx of complexities in the organisation

(C) AesthetixMS 2020. This Open Access article is published under a Creative Commons Attribution Non-Commercial 4.o International License (http://creativecommons.org/licenses/by-nc/4.o/), which permits non-commercial re-use, distribution, and reproduction in any medium, provided the original work is properly cited. For citation use the DOI. For commercial re-use, please contact editor@rupkatha.com. 
of social spaces demand novel approaches in examining the practicality of identity in consideration with the variability of societies. Thus identity becomes a socialising experience that "neither imprisons (as does much in sociology) nor detaches (as does much in philosophy and psychology) persons from their social and symbolic universes" (Davis, 1991, p. 105). Its critical engagement with the subjective and social elements determine the praxis of understanding the question "who am I." Cultural theorist Stuart Hall's (1996) critical statements on identity are crucial at this juncture. His synthesis of identity as an attribute subjected to transformation and fragmentation challenges conventional perspectives of the same. Hall's interventions emphasise on construing identities under historical and institutional sites to understand their engagement with power relations in societies. Put in this context, the essay investigates the dynamic representation of human identity in one of the contentious world areas in the middle east, the State of Israel. The problematic nature of the identity of the state's minority group (Arab Israelis) is analysed to highlight the interplay of hegemonic practices and their repercussions on the marginalised population.

The arguments are formed based on their manifestations in Arab literature produced in Israel. The literary text selected for close reading is Dancing Arabs (2004) written by Sayed Kashua, Israel's most prominent Arab voice. Born as an Arab citizen of Israel, Kashua has experienced the ambiguity of Arab identity in the state of Israel. His novels, written in Hebrew, capture the images of confused Arabs living under claustrophobic condition among Israel's Jewish majority. The unnamed narrator of Dancing Arabs, born in an Arab village in Israel, is accepted to a prestigious Jewish boarding school in Jerusalem. The new environment fiddles him and makes him struggle with his identity of a helpless Arab in a dominant Jewish atmosphere. Although reluctant at the beginning, he gradually develops fascination towards Jewish ways and makes frantic attempts to identify a space for him among the Jews. He falsifies his identity of an Arab and fakes Jewish identity only to forfeit both. His attempts to become a Jew by the dismissal of his identity as an Arab perplexed him between "who he is" and "what he wants to be". Kashua suggests that his hero is constantly on run, trying to identify himself in a land where identities are imprisoned within the sociopolitical spectrum. Kashua's hero is equally a Palestinian and an Israeli but fails in discovering a specific identity where he can place himself. The novel is not just another story of a desperate man's desire for a new space, but a serious contemplation on the repercussions of hegemony and dominance in a plural society like Israel. Kashua's narrator is provocative and struggles to disentangle his personal and national identities, only to find himself sliding between the two. The primary argument of the essay is that the complexity Arab identity in Israel is predisposed by the state's practice of ethnic-democracy in which the Arab minority is enforced to desire for their assimilation into the Jewish social space as an attempt to break the hegemony and dominance in the existing social system of Israel.

\section{Theorising Identities: Israel's Arab Minority}

Identity, as a fluid and complex component of the self, requires greater attention especially in a plural society like Israel. The volatile atmosphere of the state has ratified identity as a contentious phenomenon posing tensions between the major ethnic groups of the state. The question of a distinct national identity is constantly under dilemma as the ethnic backdrop of both Jews and Arabs emphasise on an inexorable distinction between their identity and citizenship. The discrepancy between a unified national identity and citizenship is understood when Israel's development into a sovereign state is traced back from history. With the rise of Jewish national movement Zionism in the latter part of 19th century, the prosecuted Jewish diaspora, especially in 
the central and eastern Europe, hoped to mark an end to their predicament caused by the paranoia of racial hatred. (gilbert, 1999) The murder of six million Jews in the Holocaust (Johnson, 1988) was an unadorned reality of Jewish plight that had accentuated the need for a Jewish national homeland. The ancestral land of Eretz-Israel, then Palestine was chosen by the Zionist leaders as an ideal landscape for Jewish settlements. (Liebman, 1970) However, the indigenous Arab population of Palestine strenuously opposed the influx of Jewish refugees as they viewed it as a protraction of Western colonialism. When Israel proclaimed independence in 1948, around $20 \%$ of Arabs remained within the borders of Israel towards the end of the Arab-Israeli war, referred to as al-Nakba meaning catastrophe in the Palestinian narrative. (Sa' di \& AbuLughod, 2007) This population of Arabs who chose to stay in Israel became Israeli Palestinians or Arab Israelis. Majority of Israeli Arabs embrace Palestinian nationality though they are Israeli citizens, a contradiction that has destabilized the possibility of a unified national identity in Israel. The incessant tensions between Jews and Arabs deny any possibility of psychosocial reconciliation for different existential reasons. In every stranger, Jews see a potential enemy and the Arabs are no exception. The rising disapproval by the Arabs against the Jewish state has further strengthened the spirit of Jewish nationalism and anything that stood against their motive was considered as a threat to Jewish collective identity.

But the social and political assimilation of Arabs into the mainstream is inevitable for the emergence of unified national identity, since it is a collective phenomenon conceded by the individual members of a national group. (Kelman 2016) But in Israel, this phenomenon is unattained since both the groups struggle over ownership to the same land and deny the rights of each other. Over half of the Arab Israelis reject Israel's legitimacy as a Jewish democratic state. On the other hand, a significant part of the Jewish population is willing to initiate equality as long as the Arab intentions do not weaken the Jewish characteristics of Israel. Both the groups possess logical claims to further their causes but the possibility of a peaceful and shared society is probable only through the acceptance of socio-ethnic realities and differences. Unfortunately, the septuagenarian state is incessantly criticised for the unequal distribution of power and resources among its citizens, widening the social gap between Jews and Arabs living under different conditions within the same state. One of the critical consequences of Israel's social disparity is identified as the problematic formation of Arab identity. As Kelman (2016) states, "in conflicts such as that between Israelis and Palestinians, in which the two sides live in the same space and claim ownership of the same territory, it is not only the actions of the other but also the identity and the very existence of the other that are a threat to the group's own identity." ( p. 191-192) As individuals tugged out of the group, Arab Israelis find themselves caught between the two extremes of identity formation i.e., the identity emerging from their cultural and ethnical associations and the identity which is an extension of their citizenship in Israel. So, how do hegemonic societal practices and social exclusion affect the facets (both subjective and national) of Arab identity in Israel? A close reading of the text Dancing Arabs shall provide insights into the reality of equivocal identities reacting to power and hegemony in Israeli society. The need for exploring the nuances of personal identity in Israel reflects the complexity of identity formation in plural societies. Though the land is accounted for Jewish-Arab coexistence, the unremitting conflicts stemming from ethnic and religious disputes have disoriented the collective national consciousness in Israel. 


\section{Contentious Identities in Dancing Arabs}

In Dancing Arabs, Kashua explores the conflict between the empirical formation of personal identity and the desire to fit into a new identity for social and psychological satisfaction. The novel's protagonist is an Arab tricked into the conflict of identities when he is exposed to a Jewish environment. His life in the Hebrew school, which is metaphorically the prototype of a Jewish dominant space compels him to interrogate his subjective identity as inferior. The glimpses of racial bias and exclusion force him to conclude that his Arab identity will not dilate his social life in Israel, resulting in his fascination towards Jewishness.

They're laughing at our names, and we don't do anything about it. To take part in the general hilarity would be ridiculous, so I keep quiet. They start singing something that sounds familiar, but instead of "The Jew is dead"- the way we sing it- they sing "Mohammed is dead." They sing loudly, and some of their classmates join in. I press the STOP button. The hell with Adel. I am getting off. I pick up my bag, controlling myself, holding back my tears. (Kashua, p. 97)

This instance from the novel is a painful reflection of humiliation experienced by the Israeli Arabs diurnally. The protagonist, even in his early childhood is inflicted with the bitterness of social segregation. He, along with his Arab friends was ridiculed for their identities as Arabs. His life in the Jewish school becomes miserable as he was constantly being bullied for his peculiarities as an Arab. However, the segregation was mutually directed from both sides. In the Arab villages, Jews were publically mortified and hated. But the status of Arabs as a minority weakened their spirits and elevated intolerance when exposed to Jewish communities. However, the social reality of excluding Arabs from the mainstream politics of Israeli society is undeniably the major factor in the disruption of the peace-making process between the Jews and the Arabs in Israel. But these episodes of discrimination were blatant spots which highlighted the superiority of the dominant group in all sectors of the society. Kashua validates the possibility of developing a desire, especially among the young Arab Israelis to fit into the Jewish space that provides social and economic sophistication. This process is channelised through the protagonist of the novel who disguises a new identity to blend into the Jewish community. He imagines that his existence in Israel is meaningful and productive only when he succeeds in his desire to fit in as a Jew.

I look more Israeli than the average Israeli. I'm always pleased when Jews tell me this. "You don't look like an Arab at all," they say. Some people claim it's a racist thing to say, but I have always taken it as a compliment, a sign of success. That's what I have always wanted to be, after all: a Jew. I have worked hard at it, and I've finally pulled it off. (p.91)

His intention is not a mere representation of an amateur fancy but a deep-rooted desire to appropriate his self for social acceptance. He believes that his acceptance in Israel is possible only if he falsifies his identity of an Arab. It is not his aversion or dissatisfaction towards his ethnic roots, but an intense desire to be a member of the dominant group. Hall (1996) argues that identity is constructed by the "recognition of some common origin or shared characteristics with another person or group, or with an ideal. .." (p.2) But the protagonist here discards identification with his origin, ironically to be recognised under a different identity, a tendency rooted in the reality of deep social division. As an Arab, he feels marginalised and negated from progress in Israel when compared to the Jewish majority. His longing for a fake identity evolves from the urge for acceptance in society, pointing at an intense hegemonic practise which forces the members of the minority group to yearn for equal status. Gramci (1971) enumerates hegemony as a relationship of dominance observed between two groups of people. He breaks down the Marxist concept of the superstructure (1859) into "civil society" and "political society" (Bates, 1975, p.353) 
to observe different forms of dominion. He states that the ruling class strives power over both civil and political societies that organise a state. Put in this context, the protagonist's experiences during his student years in the Jewish school can be construed as a quintessential model of civil society which constitute "schools, churches, clubs, journals and parties." (Bates, 1975, p.353) The protagonist being accepted to a prestigious Jewish school encounters several instances where his identity as an Arab in Israel is disdained and pitied. "In my second week at school I bought myself some pants in a Jewish store. I bought a Walkman and some tapes in Hebrew. After that, I'd always have my Walkman and a book in Hebrew whenever I went through the airport." (kashua, p.101-102) Arabs were unjustifiably demeaned and ridiculed even on public occasions for anything that distinguished them from the Jews. The protagonist, when exposed to the Jewish space, experiences the heat of discrimination and hostility. The divide between the two groups was visible and he realises that as an Arab, he will not be accepted as equal to the Jews. At this juncture, he develops the need to conceal his Arab identity and forge Jewish identity to be recognised in the mainstream which is unarguably the consequence of an organised hegemony. Unfortunately, he forfeits at his venture as his desire is socially dismissed especially when national identification is validated by the dominant group. Here, the protagonist's unattained identity emerges from what Hall (1996) enumerates, the interplay of power relations, highlighting social exclusion and difference.

\section{“Once an Arab, Always an Arab"}

A unified national identity in Israel is complex as the collective self of the state is divided between the two claimants (Jews and Arabs) under their socio-historical treatises. The two ethnic groups share the least hopes of reconciliation and Israel's accolade as a Jewish national homeland further complicates the possibility of integration. Social exclusion of Arabs in Israeli society has ignited the revival of Palestinian nationalism among Israeli Arabs. It is to be perceived that the Israeli component of Arab identity works for pragmatic purposes of living within a state whereas the Palestinian component is intense in defining the homogeneity of the Arab community. Contrary to the political image of Arab identity in Israel, Kashua's novel proposes a diverse dimension where the Arabs are forced to detach from "who they are" and assimilate into the majority for recognition and progress. The novel implicitly reproaches social stratification for denying the creation of a collective national identity in Israel. Though the protagonist of the novel develops fascination and curiosity towards the privilege of being a Jew, his inclination towards the dominant group and the dismissal of his ethnic roots as an Arab can be interpreted as responses to the rejection and humiliation he has confronted for being an Arab in Israel. Instances from the early life of protagonist explain the impact of social exclusion on his later attempts to forge a new identity for social acceptance.

They didn't notice I was an Arab. Every time the soldiers told an Arab to get off, I'd get up and shout, 'Take me off too, I'm an Arab! And I'd hold up my ID card and wave it proudly. What's the matter with you? What a jellyfish you are. Some soldier jerk can make you behave like this? Just look at yourself. (Kashua, p.101)

The protagonist, in the beginning, expresses agitation when he realises that the hatred channelled against his community evolves from their identification as Arabs. Their status as religious, ethnic and economic minority denies social assimilation, leading to a problematic representation of their identities in the state. Social psychologist Nick Hopkins (2011) discusses various approaches towards this concern in plural societies. He states that some minority groups 
"secure national inclusion" through assimilation whereas some affirm their "minority distinctiveness." (p. 253) However, in this case, Arabs are repudiated from national assimilation since the state perceives them as threats to national security. On the other hand, minority distinctiveness is also challenged since the Arab Israelis belong to the greater Arab nation where they were, perhaps still are mistrusted as traitors who remained in Israel. Hence, even the duality in minority identities becomes most problematic as the hegemonic structure of the state obstructs any attempts of assimilation. This obstruction is ostensibly a critical attribute to the strengthening of Palestinian nationalism among Arab Israelis, denying the possibility of coexistence. This comes across very clearly in the novel.

My father says, Once an Arab, always an Arab. And he's got a point. He says the Jews can give you the feeling that you're one of them, and you can really like them and think they're the nicest people you've ever known, but sooner or later you realize you don't stand a chance. For them you'll always be an Arab. (Kashua, p.106)

An Arab is allowed to desire for what the Jew has but there is no promise of acceptance or integration. It is also to be noted that this desire of "fitting in" does not always refer to the rejection of their source culture, rather it is an attempt made to experience equal growth opportunities as progress is inevitably influenced by the norms of the dominant group. Here, the basic premise of Gramsci's hegemony, the one with which many theorists disagree comes into play. He draws an analogy between the founding principles of the ruling class and what he calls weltanschauung or the world view. (Bates, 1975) Gramsci argues that man is ruled not only by force, but he is also oppressed by the ideas of the dominant group. The hegemonic propaganda of Jewish majority is built on the idea that the Arabs, even if they are the citizens of Israel, challenges the internal security of the state. They are treated with suspicion and are fastened to the peripheries based on the collective dominant idea of Arabs as a potential threat. Kashua states that there is no possibility of fullest Arab assimilation into the Israeli society "because the very intelligibility of the ethnic landscape in contemporary Israel (and thus the "Jewishness" of the state) depends on maintaining the Arab-Jew divide," (Rottenberg, 2008, p. 102) specifically based on what Gramsci notes the weltanschauung.

Israeli sociologist Sammy Smooha is a strong critic of Israel's ethnic democracy. In his groundbreaking essay Ethnic Democracy: Israel as an Archetype (1997), Smooha discusses the ambiguous future of Israeli Arabs caught between their aspirations and the reality of an ethnic oriented society.

Israelization process made them bilingual and bi-cultural, without their being assimilated into the Jewish majority. Even today they have high Israeli standards and aspirations. They are resigned to their fate as Israeli citizens and see their future in Israel, hoping that a solution to their plight will be found within the framework of the state of Israel and not by disconnecting from it. (p.214)

The weakness of Israeli democracy (Shapia 1997) deepens the conflict and reconciliation remains unattainable until the state observes equal accommodation of its citizens. Kashua through his fictional account condemns the practising reality of the state which consciously denies even the slightest possibility of Arab integration to the state as its ideological image foregrounded only in Jewishness. Though the Arabs are hostile towards the state's explicit inclination towards its Jewish populace, Kashua detects a desire among the Arab citizens to accept Israel as their nation, especially when they are unable to completely participate in the Palestinian national culture due to their equivocal identities. The novel maps "how a subject who identifies as part of the subaltern ethnic group is allowed and often pushed to desire norms 
associated with the hegemonic ethnic group." (Rottenberg, 2008, p. 102) The imposed inclination towards Jewish environment has been discussed and encouraged among the young Arabs and they were made to believe that sophistication and probability of progress are heightened if they try to fit into the space of Jews in Israel. This unintentional manipulation has threatened the Arab adults who are aware that they will never be accepted in the Jewish community, neither would their Arab identity be acknowledged for assimilation and equal progress.

\section{Conclusion}

Kashua's implication of imposed desire to "fit-in" emerges from the social stratification in Israel where Arabs are underrated and denied the possibility of collective Israeli consciousness. Thus, the problem of the Arabs is the conflict between "what he is" and what the society makes him "desire to be". Arabs born in Israel are not hesitant to reveal their ethnic roots, nor do they wish to identify themselves as Jews. They are brought up as proud Arabs in the state of Israel with their strong religious and cultural ideologies. But the shift in their social outlooks evolves when they engage in social interactions leading to the reality of Arab marginalisation and degradation in Israel. The contact with Jewish environment has enforced a sense of awe or desire to access the privilege that accompanies the state of "being a Jew". Kashua traces this process in the narrator's shift from an all-Arab space to a Jewish space where he develops the first instances of the "desire to fit-in". His access to the Jewish school provides him with the possibility to get acquainted with the two distinct ethnic spaces with peculiar distinctions. Though he was ridiculed and isolated by the Jewish students in the schools, he further develops an affinity towards the ideologies and sophistication of the Jewish society and desires fit himself among the Jews. He changes his attire, attempts to speak like the Jews and even falls in love with a Jewish girl who later confesses that her orthodox Jewish family would never accept an Arab son-in-law. The need to create a Jewish identity emerges out of the very denial of his ethnic roots as an Arab. His cross-cultural and crossreligious experiences make him caught between two extremes but ends as an outsider.

Anselm Strauss in his work Mirrors and Masks; The Search for Identity (1997) states that every individual has an illusion when some object or event is pinned down that he knows what it is and there is a tendency to boast that at least, a tiny portion of the world is known to them. But when the object is disconnected or stepped out of character, he no longer can understand what it was and the object does not remain the same when placed in a different or no environment. He argues that there is even the possibility that it was never what you thought it would be. Then how does a man assess it? How does he define it or act towards it? And who is he, himself, in relation to it? Dancing Arabs questions man's ability to fulfil the requirements for understanding an object or an event in particular. Kashua's narrator imagines that he is capable of embracing Jewish identity, acknowledging every single element of it. But when his conception of Jewishness is placed out of his psychological landscape, he finds it completely strange and alien. He is incapable of going back to his ethnic identity as he has ignored the possibility of identifying himself as an Arab in Israel. Similar to Strauss's observation, Kashua conjures the image of an individual who is incapable of assessing his actual identity. He is lost, not knowing whom he is concerning what he wants to be. Here, the chaos is more complicated as the individual is dangling in between the spectrum of nationality. The incapability to identify a parallel between his Arab identity and Israeli citizenship cause a rupture in his social life, slandering him as a misfit in society. Though the author has not generalised the degradation of Arab life in Israel, it indisputably directs at the plight of Israeli Arabs. The protagonist, who is a victim of Israel's ethnocentric approach, poses himself as a nightmare to the young Arab Israelis whose uncertain future is complicated amidst 
the politics of the state. It's a despairing truth that the acceptance of Arabs in Israel is still a debatable query even years after the state's establishment as a democratic country.

\section{Funding Disclosure}

The researcher acknowledges the financial support rendered by Indian Council of Social Science Research (ICSSR) by the award of Centrally Administered Full-Term Doctoral Fellowship. [File No. RFD/2019-20/GEN/CULT/149]

\section{References}

Bandura, A. (1977). Social learning theory. Prentice Hall ; Toronto.

Bates, T. R. (1975). Gramsci and the Theory of Hegemony. Journal of the History of Ideas, 36(2), 351-366. http://www.jstor.com/stable/2708933

Davis, F. (1997). The Politics of Accommodation: Settling Conflicts of State and Religion in Israel. Jerusalem.

Gilbert, M. (1999). Israel: A history. Random House.

Gramsci, A. (1971). Selections from the prison notebooks of Antonio Gramsci.

Gubrium, J. F., \& Holstei, J. A. (200o). The self in a world of going concerns. Symbolic Interaction, 23(2), 95115. https://doi.org/10.1525/si.2000.23.2.95

Hall, S., \& Gay, P. D. (Eds.). (1996). Questions of cultural identity. Chronicle Books.

Hopkins, N. (2011). Dual identities and their recognition: Minority group members' perspectives. Political Psychology, 32(2), 251-27o. https://doi.org/10.1111/j.1467-9221.2010.00804.X

Johnson, P. (1988). A History of the Jews. Harper Perennial.

Kashua, S. (2004) Dancing Arabs (M. Shlesinger, Trans.). New York: Grove Press.

Kelman, H. C., \& Fisher, R. J. (Eds.). (2016). Herbert C. Kelman: A Pioneer in the Social Psychology of Conflict Analysis and Resolution. doi: 10.1007/978-3-319-39032-1

Liebman, M. (1970). Israel, Palestine, and Zionism. The Socialist Register, 89-109.

Piaget, J. (1963). The origins of intelligence in children.

Rottenberg, C. (2008). Dancing Arabs and Spaces of Desire. TOPIA: Canadian Journal of Cultural Studies, 19, 99-114. doi: 10.3138/topia.19.99

Sa'di, A. H., \& Abu-Lughod, L. (2007). Nakba: Palestine, 1948, and the claims of memory. Columbia University Press.

Schachter, E. P. (2005). Context and identity formation. Journal of Adolescent Research, 20(3), 375-395. https://doi.org/10.1177/0743558405275172

Shapira, Y. (1977). Democracy in Israel. Ramat-Gan.

Smooha, S. (1997). Ethnic Democracy: Israel as an Archetype. Israel Studies, 2(2), 198-241. doi: 10.1353/is.2005.0060

Strauss, A. L. (1997). Mirrors \& masks: The search for identity. Transaction Pub.

Vygotsky, L. (1978). Mind in society. Harvard University Press. 
9 Hegemony, Exclusion and Equivocal Identities: Reflections on Israel's Arab Minority in Sayed Kashua's Dancing Arabs

Neha Soman is an ICSSR Doctoral Fellow of English at Bharathiar Universito, Tamil Nadu. She Works on Area Studies to examine the interplay of community, place and Identity in world areas. Central focus of her study is the possibility of coexistence in war-torn nation states. She is also an active blogger at Word Press. 